\title{
Forest disturbance and cropping mixtures influence crop raiding by red-tailed monkey and grey-cheeked mangabey around Mabira Forest Reserve, Uganda
}

\author{
Bernard Fungo $^{1 *}$, Gerald Eilu${ }^{1}$, Mnason Tweheyo ${ }^{1}$ and Deborah Baranga ${ }^{2}$ \\ ${ }^{1}$ Department of Forest Biology and Ecosystems Management, Makerere University, P. O. Box 7062, Kampala-Uganda. \\ ${ }^{2}$ Department of Zoology, Makerere University, P. O. Box 7062, Kampala-Uganda.
}

Accepted 20 June, 2011

\begin{abstract}
Communities around protected areas frequently complain of wild animals destroying already limited crop fields, with little or no assistance offered by conservation stewards towards the mitigation of crop raiding losses. The aim of this study was to find out whether forest disturbance gradient and crop mixtures influence the level of crop raiding by the red-tailed monkey (Cercopithecus ascanius larvatus) and the grey-cheeked mangebey (Lophocebus ugandae). The study was conducted in sample plots from seven village enclaves surrounding the Mabira Forest Reserve in central Uganda. Crop raiding was highest in the maize-cassava (Zea mays-Manihot esculenta) and least in banana-coffee (Musa sp.Coffea sp.) cropping mixtures. Crop raiding among disturbance zones was higher in the more disturbed production zone, but did not differ between the low and moderate disturbance zones (nature reserve and recreation buffer). Results show that crop raiding by the two primate species is enhanced by forest disturbance that encourage either very limited or extensive forest disturbance. However, the gravity of crop raiding is also determined by the cropping systems practices by communities around the forest. Planting mixtures of highly susceptible crops such as maize and less susceptible ones such as coffee, as well as following recommended weeding regimes can reduce the level of raiding. Compensation schemes should be disaggregated according to disturbance (or management zones).
\end{abstract}

Key words: Forest disturbance, crop mixtures, primates, crop raiding, Mabira forest, Uganda.

\section{INTRODUCTION}

Crop raiding by wild animals can make rural livelihoods more marginal (Boulton et al., 1995; Else, 1991; Infield and Namara, 2001). Communities around protected areas frequently complain of pests such as monkeys and baboons destroying large amounts of the limited crop yields with little assistance offered by conservation stewards towards the mitigation of crop raiding losses (Haule et al., 2002; Tweheyo, 2003). In many cases, the impacts of crop raiders can be devastating, for example, a farmer's whole crop may be destroyed in one night (Hill, 1998). A study around the Budongo Forest Reserve in Uganda (Hill, 2000) found that the cost of crop-raiding and guarding varied from US\$ 96-519 per household per

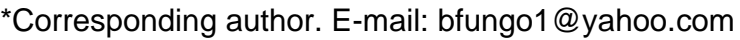

year. Considering the average local salaries in this area of only US $\$ 25$ to 30 per month (Hill, 2000; Haule et al., 2002) this loss is substantial and calls for a solution from wildlife managers.

Crop raiding is a source of conflict between conservation stewards and local communities. Studies of crop raiders around Budongo Forest Reserve (Hill, 2000; Tweheyo and Obua, 2001, Fungo, 2011) and Kibale National Park (Naughton-Treves, 1998; Chiyo et al., 2005) recorded substantial losses incurred by farmers. Understanding the socio-economic and cultural aspects of the interaction between humans and wildlife should be examined to find practical solutions to the increasing human-wildlife conflicts around protected areas (Stanley and Griffith, 1997). Some of the aspects to consider include wildlife populations under threat, human communities enduring threats, behavioral characteristics 


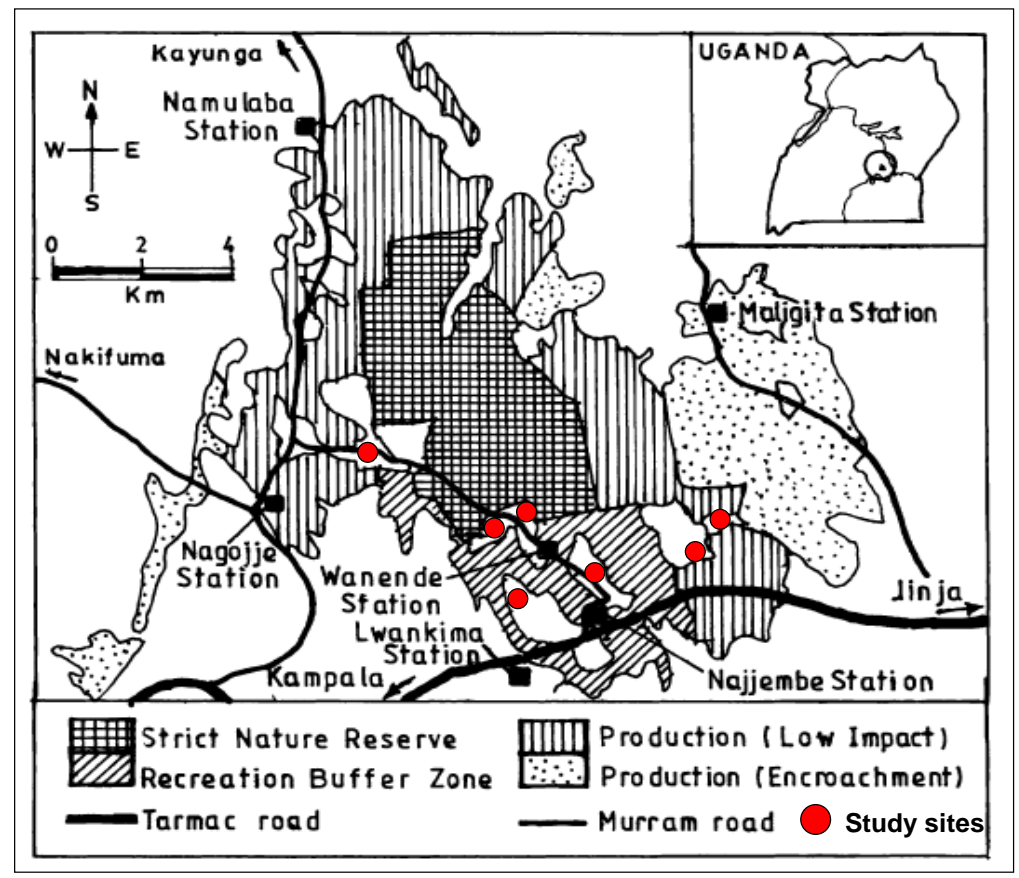

Figure 1. Location and management zones of Mabira Forest Reserve, Uganda. Adapted from Baranga (2007).

of raiders and agencies responsible for alleviating the problem. Particular attention should be paid to the needs of the different parties. Zoning of forest and the subsequent differences in management and use practices can influence forest ecology, relative abundance and hence the extent of raiding that wild animals are likely to cause to the crops around protected areas (Chinea, 2002). Additionally, cropping systems and practices are important because they influence food concentration and access by crop-raiders.

According to the optimal foraging theory (OFT) (MacArthur and Pianka, 1966; Krebs, 1978; Pyke et al., 1977; Maynard, 1978; Isawa et al., 1981; Pyke, 1984; Schoener, 1971), the behavior of crop raiding wild animals will depend on food availability (quality and quantity) and distribution, ease of movement to and from the food source, among other factors. In response to food scarcity, crop raiding animals obey the resource defense theory, which asserts that to improve access to food; the animals tend to live in groups (Krebs, 1980; Mole, 1994). In terms of raiding intensity, this has significant implication for small-scale farmers living around the forest reserve. Mabira Forest Reserve is under different management zones, reflecting the level of disturbance, and this could have effect on crop raiding patterns and intensity. In the face of changing forest structure and composition, and cropping patterns, the foraging patterns of crop-raiding primates in the forest will likely impact the food security condition of farming households around the forest reserve.

We hypothesize that forest degradation as influenced by the use practices in the different management zones will significantly affect quality, availability, distribution of primate food sources and mobility in the forest. This will, in turn influence the intensity of crop raiding by nonhuman primates in the forest. This effect will further be conditioned by the cropping patters on farmers' fields because of the variability in forage and mobility characteristics. Understanding the interrelationships among these variable is crucial to addressing the duo challenge of food security and forest conservation. This study addressed the interrelationships among forest disturbance gradient and cropping systems. Therefore, the aims of this study were to: (1) determine the daily and seasonal patterns of crop-raiding by red-tailed monkey (Cercopithecus ascanius larvatus) and the grey-cheeked mangebey (Lophocebus ugandae), (2) determine the influence of cropping systems on crop-raiding and (3) compare crop raiding under different forest management zones of the Mabira Forest Reserve.

\section{MATERIALS AND METHODS}

\section{Study area}

\section{Location, climate and topography}

The study was conducted in village enclaves of Mabira Forest Reserve $\left(0^{\circ} 24^{\prime}\right.$ and $0^{\circ} 35^{\prime} \mathrm{N}$ and $32^{\circ} 52^{\prime}$ and $33^{\circ} 07^{\circ} \mathrm{E}$, Figure 1), located $54 \mathrm{~km}$ from Kampala City and $26 \mathrm{~km}$ from Jinja, the second largest town in Uganda. The forest covers an area of $306 \mathrm{~km}^{2}$ $(31,293 \mathrm{ha})$ traversing Mukono and Kayunga districts of Uganda. Mabira Forest Reserve is a medium altitude forest, located between 
1070 and $1340 \mathrm{~m}$ above sea level, occupying gently undulating plains with numerous flat-topped hills and wide shallow valleys.

The topography is such that the drainage is to the north, away from Lake Victoria, even though the reserve's southern boundary lies only $13 \mathrm{~km}$ from the shores of the lake. The reserve is bounded with numbered concrete posts at the corners and direction trenches and isolated from other protected areas by agricultural land. The area receives two peaks of rainfall from March to May and September to November with mean annual rainfall of 1200 to 1500 $\mathrm{mm}$, and average temperatures of $26^{\circ} \mathrm{C}$.

\section{Fauna and flora}

Mabira Forest Reserve is the largest block of moist semi-deciduous forest remaining in central Uganda (Carswell, 1986). The reserve is considered a secondary forest with distinct sub-climax vegetation communities and a wide range of fauna. The reserve has 312 shrubs, 287 birds, 23 small mammals, 218 butterflies and 97 moths (Forest Department, 1996). The tree species include Diphasia angolensis not known to occur elsewhere in Uganda, Milicia excelsa, Cordia millenii, Irvingia gabonensis, Entandrophragma angolense and Lovoa swynnertonii from this reserve are listed as endangered (Forest Department, 1996). Because of the species diversity, Mabira Forest Reserve is therefore a good conservation area to protect the various assemblages of species. The ecology and social system of the grey-cheeked mangabey and Red-tailed monkeys has been documented by several studies (Cords, 1984; Baranga, 1995; Chapman et al., 2000a; Chapman et al., 2000b)

\section{History and management}

Several communities existed inside the forest before its designation as a Forest Reserve in 1932. These communities are about 3 to 5 square kilometers, hosting between 30 to 50 households. At the time of gazating the reserve, the boundaries were made in such a way that they exclude the communities, thereby forming villages enclaved by the forest. These communities coexisted with the forest with minimum disturbance until 1975 to early 1980s when the forest was seriously encroached for agriculture and settlement driven by population pressure following the Land Reform Decree of 1975. By 1988 , about $25 \%$ of the forest had been cleared for intensive coffee and banana agriculture and as many as 3,506 families had settled in the forest (Howard, 1991). The degradation was aggravated by commercial use that began when some parts were harvested for timber and charcoal in the early 1990s to feed into the nearby towns of Jinja and Kampala (Howard, 1996). Although the encroachers were evicted in 1988, illegal activities such as pit sawing, charcoal burning, collection of medicinal plants and poles for building has continued on a reduced scale by both local communities and distant traders from Kampala, Mukono and Jinja districts.

Approximately $23 \%$ (7350 ha) is a nature reserve, 29 (9,467 ha) is a recreation buffer, $33 \%$ (11230 ha) is a production-low impact and $13 \%$ (4123 ha) is production (encroachment) zone. In the strict Nature reserve, no extractive use is allowed, except where research activities are conducted, but even then, removal of material such as plant is strictly restricted. Recreation buffer zones have activities such as ecotourism and harvesting of limited plant material for medicinal purposes by local communities. Also, fuel wood harvesting is allowed two days a week and this is monitored in collaboration with community-based group (Mabira Forest Conservation Community, MAFICO). The production (low impact) zone is one where harvesting trees for timber is permitted and private firms are given concessions to harvest and latter allowed regenerating naturally. The production (encroachment) zone is where the forest is already degraded to the extent that there is no significant harvestable timber. Instead, this area is reserved for natural regeneration with some enrichment planting being carried out. For the purpose of this study, the production (encroachment) zone, which is henceforth referred to as 'production zone', was left out because it is surrounded by a sugar cane plantation with no communities around it.

\section{Methods}

\section{Research design}

The study was conducted in three zones of the forest; the nature reserve, recreation buffer and production zones. The zones were selected because they represent the different levels of human disturbance on the forest and therefore the food quality, quantity and distribution and mobility of crop raiding primates. In the nature reserve, extractive use is prohibited, implying minimal disturbance of the forest ecology. In the recreation buffer, minimal extractive use of fuel wood and medicinal plants is permitted, thus representing moderate human disturbance. In the production zone, there is more severe disturbance due to controlled logging and charcoal burning.

Various cropping patterns are practiced by communities around Mabira Forest Reserve. We selected the cropping patterns based on the susceptibility to crop raiding by the two most common primate crop raiders; red-tailed monkey (C. ascanius larvatus) and the grey-cheeked mangebey ( $L$. ugandae). Although other crop raiding animals are mentioned in by farmers, they do not pose significant threat to crop yields, and are not common raiders (Fungo et al., 2010 in press). The cropping patterns selected were maize $(\mathrm{M})$, passion fruits $(\mathrm{P})$, bananas-Coffee (BCo), banana-passion fruits (BP), and maize-cassava (MCa). (Bananas = Musa sp., Coffee $=$ Coffea sp., passion fruits $=$ Passiflora edulis, Maize $=Z$. mays, Cassava $=M$. esculenta). The cropping cycle of the farmers living around the forest is shown in Table 1.

\section{Plot sampling procedure}

Seven villages (Namusa, Kayunga, Kasokoso, Najjembe, Buwola, Sanga and Naggojje) (Figure 1) were selected. A reconnaissance survey was conducted to identify candidate plots and sampling frame was generated. Five of them were then randomly selected for assessment. Each cropping pattern was represented by five randomly selected plots and replicated in each disturbance zone. A total 75 of plots were sampled (five plots per cropping pattern $x$ five cropping patterns $x$ three disturbance zones). The layout of the plots was such that the length was parallel to the forest boundary. Crop raiding was assessed in sample plots of $50 \times 30 \mathrm{~m}$ for plots containing $\mathrm{B}$ and $\mathrm{Ca}$, and $30 \times 20 \mathrm{~m}$ for those with $\mathrm{M}$ and $\mathrm{P}$. The difference in plot size was due to differences in the number of plants per unit area. The distance of each plot from the forest edge was, on average, $200 \mathrm{~m}$.

\section{Data recording}

Information recorded in the plots included the total number of individual stems of the plants under study and number of primatedamaged plants. The animal species causing raiding were identified using direct observation (when assessing raiding frequency of primates) or secondary evidence. The growth stage of the raided crop (fruiting, maturing or harvestable) was also noted. In the case of bananas and maize, the number of plants meant those that were fruiting, (including those whose fruit had just emerged). Weed infestation was assessed on a 1 to 3 Likert scale (Likert, 1932) with one lowest and three highest level of weed infestation (Table 2). Other 
Table 1. Agricultural cycle of farmers around the Mabira Forest Reserve, Uganda.

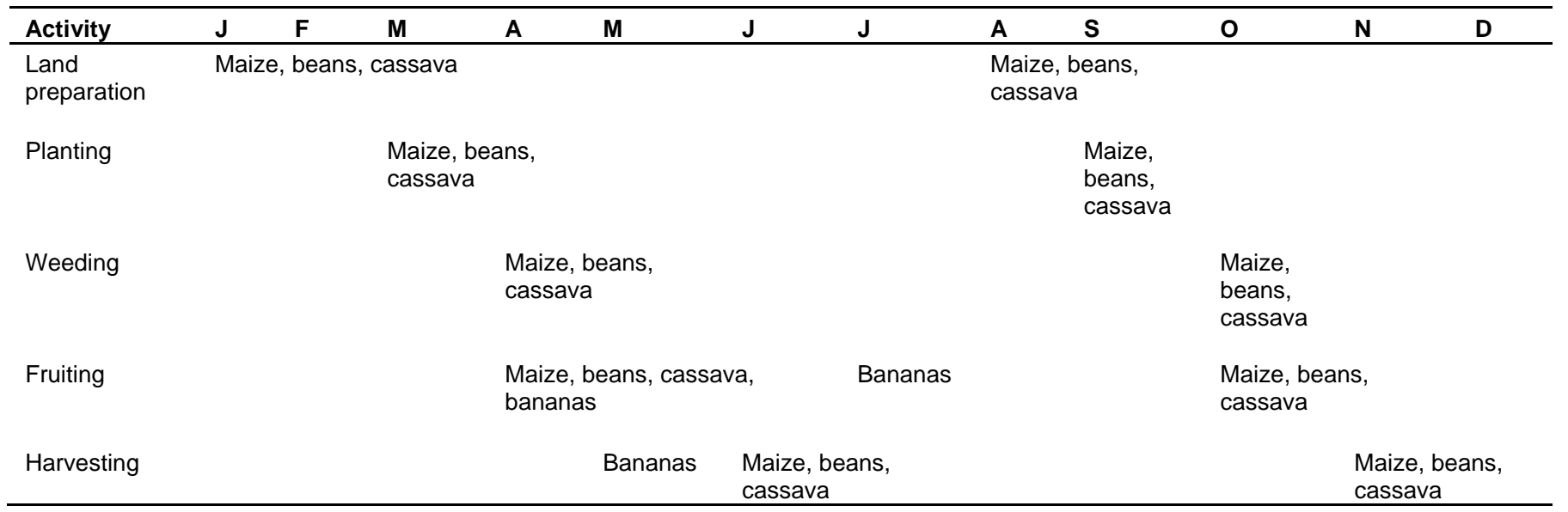

Table 2. Scale for rating condition of weeds in sample plots.

\begin{tabular}{cll}
\hline Code & Category & Description \\
\hline 1 & Clean & $\begin{array}{l}\text { Garden is either recently weeded or has emerging weed. The surface is generally void of secondary } \\
\text { vegetation that is not considered a crop in the current growing season. Smalls mammals walking through the } \\
\text { garden can be easily detected with very limited or completely no room for hiding }\end{array}$ \\
2 & $\begin{array}{l}\text { Moderately } \\
\text { infested }\end{array}$ & $\begin{array}{l}\text { Weeds have grown substantially to the extent of hiding small rodents and bush pigs cannot be detected from } \\
\text { a distance. The garden has not been weeded for a period of up to three months }\end{array}$ \\
$\begin{array}{l}\text { Heavily } \\
\text { infested }\end{array}$ & $\begin{array}{l}\text { Weeds have grown to the extent of overshadowing the crops. All crops raiders are able to effectively hide } \\
\text { among the weeds. Human movement is also impeded }\end{array}$ \\
\hline
\end{tabular}

information about the plot, such as presence of relay trees and the control measures, was recorded.

Data recording was done three times on each day, and once every week throughout the cropping season. After each recording event, the raided crops were marked (for bananas and maize) or removed to avoid double-counting. On each passion fruit plot, the passion fruits fed upon and dropped by the primates were removed. Siex and Struhsaker (1999) used this method to determine the consumption of coconuts by the Zanzibar red colobus. Fruits eaten by the primates are very distinct; the tooth bites are clearly seen. The primates do not carry passion fruits away from the garden. The number of ripe fruits on all the passion fruit vines within the plots was counted. Quantities of fruits consumed were expressed as a percentage of the total number of fruits. In order to cover the different seasons, new plots within $100 \mathrm{~m}$ were identified to substitute those where the maize crop had been harvested.

To investigate the effect of raiding time and frequency, observations in two selected plots were made at three different times of the day (Morning, 7 to 9 am; Afternoon 12-2 pm, and evening, 5 to $7 \mathrm{pm}$ ). This showed the time of the day when the gardens are most susceptible to crop raiding wildlife species. Raiding frequency focused on arboreal primate species; the redtailed monkey and the grey-cheeked Mangeabey. An average, based on the six months of sampling, was used to determine the mean percentage of fruits consumed. Daily raiding frequency (number of times primates visited a garden) was monitored in three plots selected within each management regime at four different times of the day to capture the time when raiding activities were expected to be highest. This was repeated after two weeks over a period of five months. Plot assessments were done on a weekly basis from June to November, 2007.

\section{Data analysis}

Crop raiding was expressed as the percentage of the total number of plants raided. Counts and percentage data were transformed using suitable models to make the data conform to the normality assumption of Analysis of Variance (ANOVA). ANOVA were performed in order to compare crop raiding at different times of the day, among cropping systems, weed infestation levels and among forest management zones. Means were reported as the backtransformed to the original scale. Exponential regression analysis was also performed to determine the relationship between crop raiding and gap size created by charcoal burning and logging. The Shannon-Weiner diversity indices were used to compare forest tree species diversity among forest management zones. All the statistical tests were performed using Minitab 12 at $95 \%$ level of confidence.

\section{RESULTS}

\section{Influence of forest zones on crop raiding}

The frequencies of crop raiding by red-tailed monkeys and grey-cheeked mangabeys are shown in Table 3. The 
Table 3. Cumulative raiding frequency of red-tailed monkeys and grey-cheeked mangabeys in Mabira Forest Reserve, Uganda $(\mathrm{N}=276)$. Data collected between July and November 2007.

\begin{tabular}{lcc}
\hline $\begin{array}{l}\text { Forest disturbance } \\
\text { Zone }\end{array}$ & $\begin{array}{c}\text { Red-tailed } \\
\text { monkey }\end{array}$ & $\begin{array}{c}\text { Grey-cheeked } \\
\text { mangabey }\end{array}$ \\
\hline Nature reserve & 60 & 0 \\
Recreation Buffer & 82 & 9 \\
Production & 74 & 0 \\
\hline
\end{tabular}

Table 4. Mean daily group size of red-tailed monkeys and greycheeked Mangabeys in Mabira Forest Reserve.

\begin{tabular}{lccc}
\hline $\begin{array}{l}\text { Forest } \\
\text { management zone }\end{array}$ & N & $\begin{array}{c}\text { Red-tailed } \\
\text { monkey }\end{array}$ & $\begin{array}{c}\text { Grey-cheeked } \\
\text { mangabey }\end{array}$ \\
\hline Nature reserve & 48 & $2.13(0.97)^{\mathrm{a}}$ & $0.11(0.41)^{\mathrm{a}}$ \\
Recreation buffer & 96 & $3.57(0.37)^{\mathrm{b}}$ & $0.31(0.68)^{\mathrm{a}}$ \\
Production & 48 & $2.53(0.13)^{\mathrm{a}}$ & $0.57(0.98)^{\mathrm{b}}$ \\
\hline
\end{tabular}

Column means with the same superscript do not differ significantly. Numbers in parentheses indicate the standard deviation.

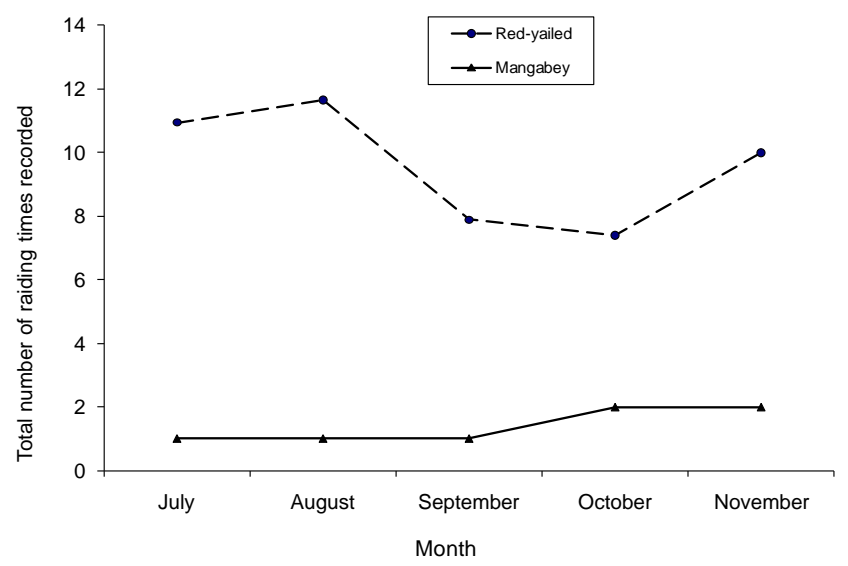

Figure 2. Mean monthly crop raiding frequency of red-tailed monkeys and grey-cheeked mangabeys over a five-month period in July-November 2007.

frequencies of raiding by red-tailed monkeys in the nature reserve and production zones did not differ significantly but was generally higher in the recreation buffer $\left(F_{2,381}=\right.$ 14.5, $\mathrm{p} \leq 0.001$ ) (Table 4). Raiding frequencies by the grey-cheeked Mangabeys were significantly higher in the production zone $\left(\mathrm{F}_{2,507}=12.4, \mathrm{p} \leq 0.023\right)$ but was nonexistent between recreation zone and the nature reserve as the Mangabays were not seep crop raiding in the zone. Comparing red-tailed monkeys and grey-cheeked Mangabeys, the latter were significantly more frequent in the gardens than the former $(p \leq 0.000)$.

Comparing the different times of a day (morning, 7 to 9 am; afternoon 12 to $2 \mathrm{pm}$, and evening, 5 to $7 \mathrm{pm}$ ), the means group sizes were $3.6 \pm 0.22,5.2 \pm 0.32$ and $3.5 \pm 0.4$ for morning, afternoon and evening, respectively. The group size of raiders was significantly larger in the afternoon than in the morning and evening $\left(F_{2,383}=16.3, p \leq 0.001\right)$ while the later two did not differ significantly. No single incident was recorded when mangabeys were raiding together with red-tailed monkeys.

\section{Temporal patterns of crop raiding}

Seasonal patterns of raiding frequencies were evaluated by grouping individual raiding frequencies according to the month in which they occurred. For red-tailed monkeys, mean monthly raiding frequencies were significantly higher in the July and August, followed by November and least in September and October $\left(F_{4,505}=\right.$ 12.2, $p \leq 0.005$ ) (Figure 2). The number of individual primates raiding gardens per month ranged from 1 to 12 . Only one Mangaby was recorded in each of the months of July, August, and September while October and November registered two individuals each per month at different locations.

For a given crop, the trend in raiding was constant throughout the sampling period but generally cassava had a lower raiding level compared to bananas, passion fruits and maize (Figure 3).

\section{Influence of cropping systems on crop raiding}

From the plot assessments, the mean percentage of garden raided were maize-cassava $(6 \%)$, banana-coffee $(13 \%)$, bananas $(18 \%)$, maize $(19 \%)$, banana-coffeepassion fruits $(24 \%)$ and passion fruits $(36 \%)$ cropping systems (Figure 4). Comparison of the levels of crop raiding among the various cropping systems showed a significant difference $\left(F_{5,505}=189.27, P \leq 0.001\right)$. Except maize and banana systems, all the others were significantly different. The maize-cassava system experienced the lowest level of raiding (6\%), followed by the banana-coffee $13 \%)$. Banana (18\%) and maize (19\%) were not significantly different but experienced higher raiding than banana-coffee. The banana-coffee-passion fruit (24) system was significantly lower than the passion fruits $(36 \%)$ but was significantly higher than the maize system (19\%).

Average crop raiding for each crop in all the plots belonging to the respective weed regimes were used as sampling units. Un-stacked One-way ANOVA was performed to separate the means in the weed level. Raiding estimates for the three weed levels were 0.1047 for clean plots, 0.1122 for moderate plots and 0.1388 for heavily infested plots $(\mathrm{N}=119,139$ and 252). Results showed that farms that were heavily infested with weeds experienced significantly higher raiding levels compared to the clean and moderately infested plots (LDS $=0.0182$, 

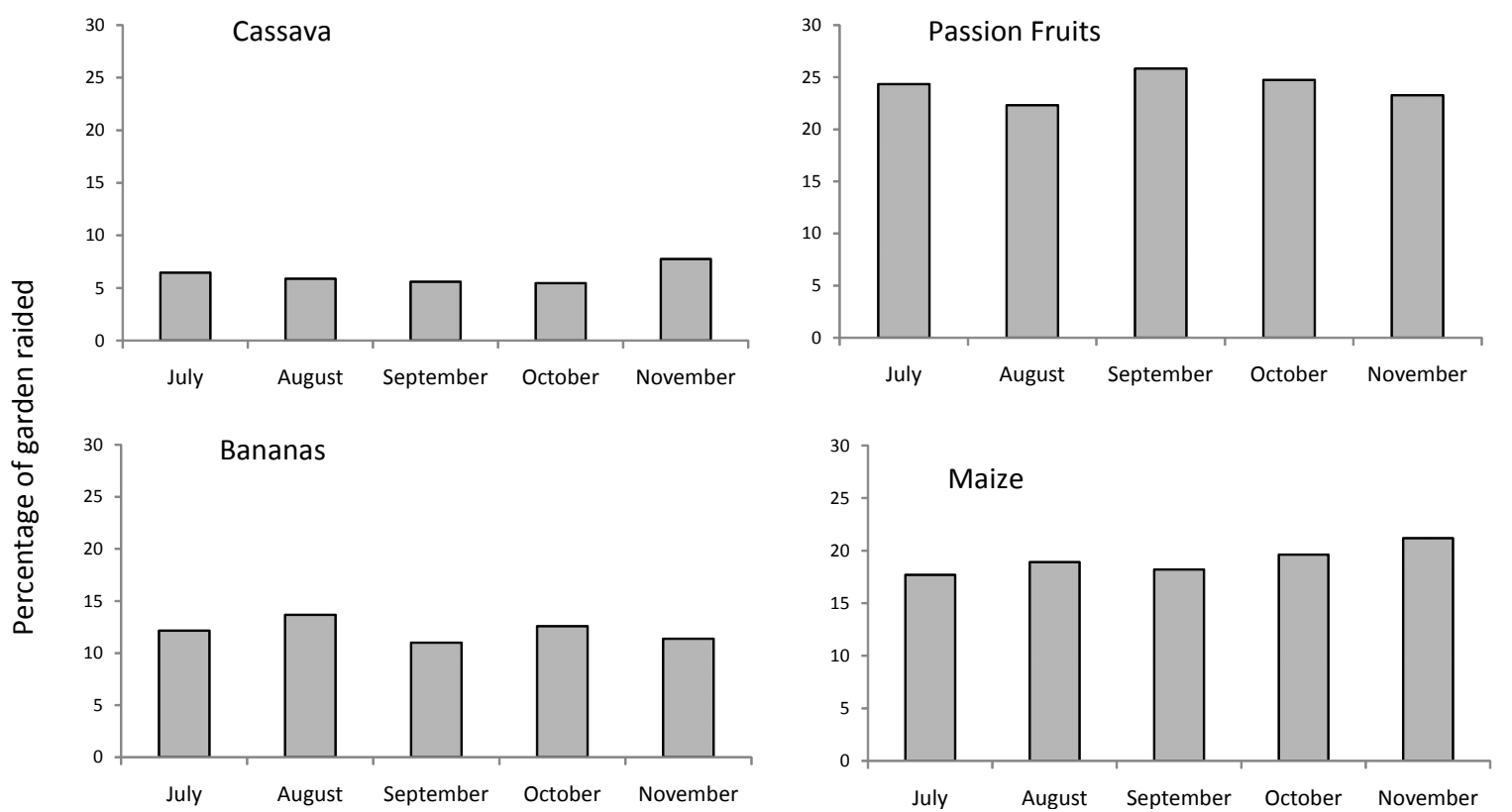

Figure 3. Proportion of gardens raided in the different seasons in Mabira Forest Reserve.

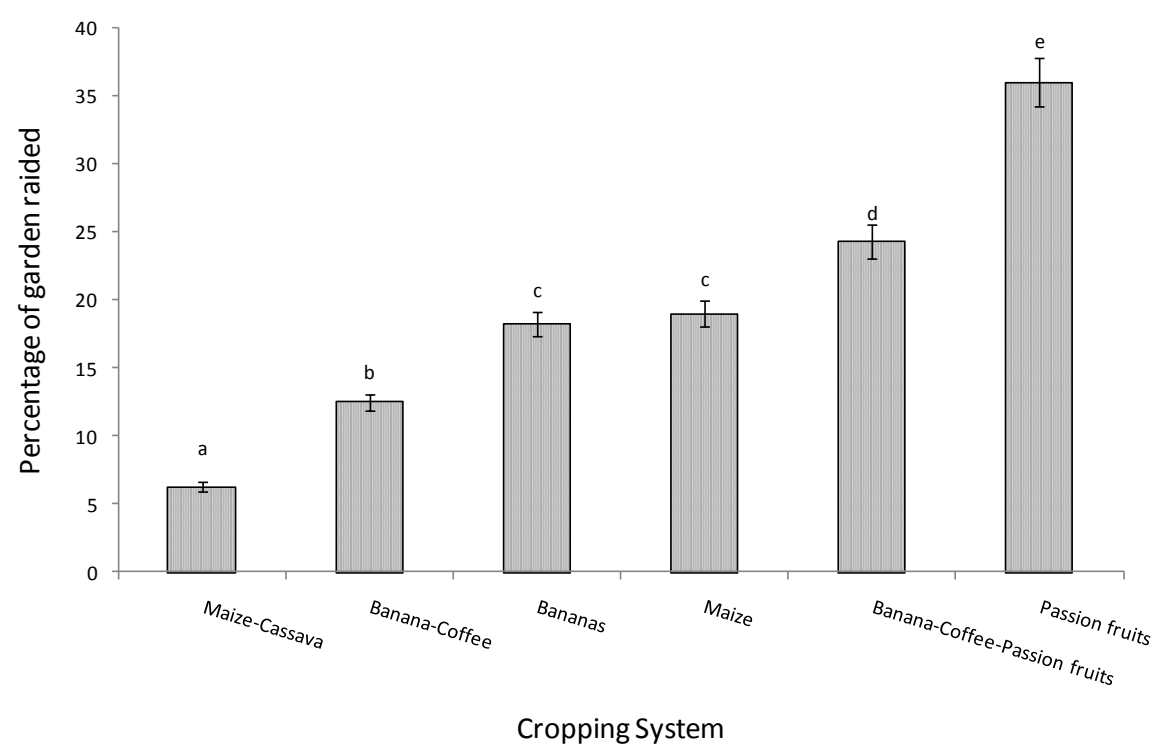

Figure 4. Crop raiding among cropping systems around Mabira Forest Reserve, (Bars with the same letter refer to means that are not significantly different at $5 \%$. Error bars represent standard error).

$P<0.001)$.

\section{Influence of forest management zoning on crop raiding}

The crops used in this analysis of the study were maize, bananas, cassava and passion fruits. Comparison of the percentages of raiding on each crop showed a significant difference $\left(F_{5,504}=14.6, P<0.001\right)$ among the crops. Passion fruits were the most raided crop (with a mean of $17 \%)$, followed by means of maize $(10 \%)$, Bananas $(7 \%)$ and least was cassava $(2 \%)$. The mean raiding estimates for the various crops among forest management regimes are shown in Table 5. Data shows that for cassava, the overall mean estimates of raiding among forest manage- 
Table 5. Farm estimates of crop raiding in relation to management zones in Mabira Forest Reserve $(\mathrm{N}=67)$.

\begin{tabular}{lcccc}
\hline \multirow{2}{*}{ Management zone } & \multicolumn{4}{c}{ Mean percentage of crop raiding in the garden } \\
\cline { 2 - 5 } & Cassava & Banana & Maize & Passion fruit \\
\hline Nature reserve & $1.5^{\mathrm{a}}$ & $9.3^{\mathrm{a}}$ & $7.7^{\mathrm{a}}$ & $16.4^{\mathrm{a}}$ \\
Recreation buffer & $1.7^{\mathrm{a}}$ & $5.8^{\mathrm{bc}}$ & $10.2^{\mathrm{bc}}$ & $12.0^{\mathrm{c}}$ \\
Production zone & $2.3^{\mathrm{a}}$ & $6.0^{\mathrm{b}}$ & $11.7^{\mathrm{b}}$ & $25.7^{\mathrm{b}}$ \\
\hline
\end{tabular}

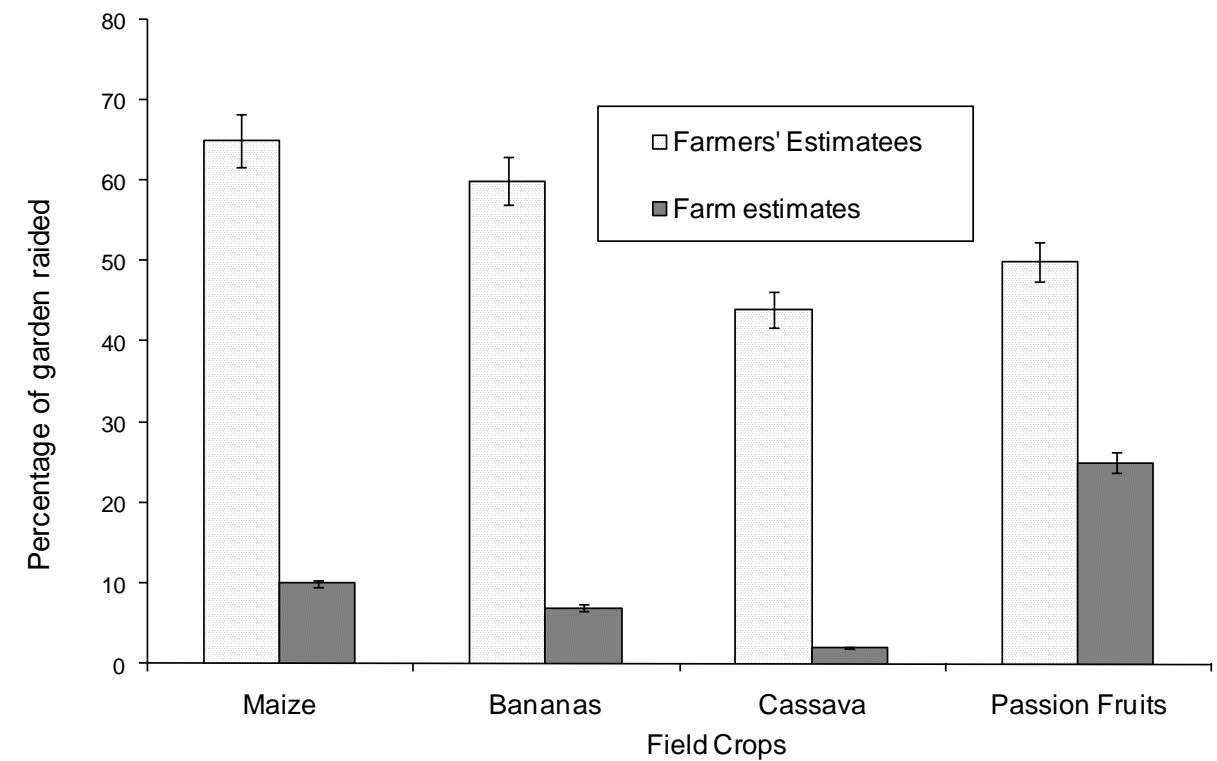

Figure 5. Farmer and plot estimates of crop raiding around Mabira Forest Reserve.

ment regimes were not significantly different $\left(F_{5,504}=\right.$ 1.25, $\mathrm{P}=0.318$ ).

Comparing these with the farmers' estimates using data from a previous study by (Fungo et al., 2010 in press) showed that for all the crops, the farmers gave much higher values compared to the actual field raiding values (Figure 5).

\section{DISCUSSION}

\section{Raiding frequency and group size of primate crop raiders}

Raiding frequency may be influenced by the relative abundance of preferred foods in the gardens or absence of adequate foods in the forest (Tweheyo, 2003; Baranga, 2007). According to Osborn (1998), the timing of crop raids by wild animals is triggered by nutritional stress caused by a decline in the quality and nutritive value of natural forage. Following the previous degradation trend of the forest, the population of Mangabeys reduced tremendously beyond that of the red-tailed monkeys. Therefore, the relative abundance of red-tailed monkeys is much higher than that of the Mangabeys. Thus, they are easy to see and also frequently engage in the raiding. From the ecological point of view, the Mangabeys are species that feed more in the interior of the forest than the red-tailed monkeys (Groves, 2007). Therefore, much of the raiding is observed to be effected by the latter of these two primate species.

The size of an animal's territory (and its population density) depends on the distribution of its preferred foods (Chiyo et al., 2005). The recreation buffer zone is a moderately disturbed forest part, implying that there is more vegetation diversity and therefore potential food reserves compared to the more degraded production and climaxing nature reserve zones. One would expect that this relatively higher food abundance would translate into fewer animals moving from the forest to the gardens as there will be food in the forest. However, the distribution of the forest foods varies both spatially and in time. The limited knowledge on the spatial distribution and relative abundance of primate foods in this forest confounds understanding of raiding frequency. In accordance with the optimal foraging theory (MaArthur and Pianka, 1966), species food searching behaviors maximize net energy intake per unit time. So, they are acting in ways to get the most calories while using the least amount of energy.

According to Tappen (1960) and Kingdon (1971), the 
cosmopolitan distribution of the red-tailed monkey is related to its ability to inhabit a wide variety of habitats, including secondary forests, montane, lowland, riverine and swamp forests, and lakeshore thickets since it favours forest edges and areas of secondary growth, it can take advantage of slight forest disturbance. Chapman and Lambert (2000) report that, the pattern of their habitat use is such that these species are frequently observed in fragments outside Kibale Forest National Park. Nevertheless, Baranga (2004) observed that in the forest fragments around Kamapala, the monkey is abundant in all areas except the most heavily logged sites where its densities have continued to decline decades after logging.

The crop raiding patterns observed in this study support the hypothesis that crop raiders are drawn to ripe crops and are not induced to raid by nutritional stress from low forage quality in accordance with the Optimal Foraging Theory (MacArthur and Pianka, 1966; Krebs, 1978). A similar phenomenon has been observed in Indian elephants (Loxonodota africana) (Sukumar, 1989; Balasubramanian et al., 1995), where raiding by elephants intensified during ripening of paddy and millet. Saj et al. (1999) also observed that vervets tended to spend more than $50 \%$ of their time budget on targeting human food, which are calorically and nutritionally superior to wild foods and differentially distributed. The resource defense theory of sociality of primates suggests that being in a group improves access of primates to resources compared to being alone (Krems, 1980; Mole, 1994). Additionally, the predation theory envisages that being in a group offers better protection from predators. July and August are fruiting months for most crops in farmers' gardens. Even the bananas, which may be thought to be perennial fruiting crops, are also in more abundant fruiting in these months.

\section{Influence of cropping systems on crop raiding}

The forest primates investigated like passion fruits, bananas and maize. It is expected that raiding on a garden containing these crops would be higher compared to other crops. Similarly, in intercrops where the major crops are preferred by raiders, raiding should be higher because of the high resource concentration. Overall, the results clearly show this trend. Forest primate raiders prefer maize, bananas and passion fruits and gardens having these crops experienced comparatively higher raiding levels. In the banana-coffee-passion fruit intercrop, a possible explanation for the relatively higher raiding level is that bananas and passion fruits are both highly preferred crops while the coffee is a somewhat conveyer where monkeys and Mangabeys normally 'hid' and can also quickly retreat to the forest after sighting an enemy. Studies of Naughton-Treves et al. (1998) suggest that planting agroforestry buffers along park edges creates ideal habitat for crop-raiders.

The relatively low level of raiding in the cassava-maize intercrop could be due to low-lying nature of the crops such that the high visibility within short range distances does not permit free access to the gardens by the major crop raiders, the monkeys. Additionally, such a cropping system usually, has fewer maize stems that primates prefer but mostly dominated by cassava that they do not raid. The ongoing discussion provides a promising explanation for the consistence of monthly patterns of raiding with previous findings (Hill, 1997; Tweheyo and Obua, 2001). Passion fruits and Bananas are perennials crops that stay in gardens for a longer time than maize. Therefore, primates always know where the food is, and many times concentrate their foraging efforts in these areas for a long time. Therefore, raiding in such areas is likely to be higher. In the annuals, the wild animals have to search for the crops every season, and sometimes the crop matures before many animals are able to identify the crop.

Gardens with heavy weeds face triple jeopardy; firstly, in most cases the farmers do not implement any control measures. Secondly, the yields are overall low due to competition from weeds. Thirdly, raiders have room to hide and concentrate their efforts when raiding. The significance of this study is that farmers reduce raiding to their crops by maintaining low levels of weed infestation. What may not be clear is the relationship between the size of the garden and the level of weeds. Sitati et al. (2005) and Naughton-Treves (2002), however, reported lower raiding level for smaller farms, attributing it to lower guarding efforts. Probably, smaller gardens belonging to poorer households that also have small family size could lower chances of guarding and weed management interventions.

By ranking it among the major factors enhancing raiding by wild animals, the farmers acknowledge that indeed good weed management practices can reduce levels of crop raiding. It is also possible that larger farms experience less percentage raiding due to resource concentration. The reasons for not weeding, as Fungo et al., 2010 (In press) observed, could be due to the fact that the youth leave older parents and go to townships in search for better-paying employment. We do not know of any use to which farmers put the weeds (fodder, medicinal, soil cover) but some studies have shown that farmers may leave gardens un-weeded due to some of these reasons.

A variety of methods that can be used to express raiding make it difficult to determine whether the figures on crop raiding are comparable or not. Hill (2000) emphasized the fact that a greater degree of clarification of the exact measures used, and how they have been manipulated by the researcher, would be beneficial when trying to decide whether results across studies are comparable or not. In addition, perhaps some standardization of methods of methods of data handling me needed. 


\section{Influence of forest disturbance on crop raiding}

The extent of raiding was consistent with previous studies such as Deodatus (2000), Jackson and Wangchuk (2000). Explaining raiding levels in different forest management zones is complicated by a wide array of plausible explanations. Does abundance of human activities in the degraded forest areas shove raiders out of the forest to the boundary, resulting in more crops raiding in the gardens. Do communities spend most of their time in the forest engaging in degradation activities at the expense of their farms? It is logical to suppose that if the forest interior is moderately disturbed, more wild foods emerge, thereby reducing primate crop raiding. On the contrary, because of their tendency to concentrate on particular types of food, it can be envisaged that wildlife crop-raiders are more concentrated at the forest boundary neighboring gardens because they want foods that are either more nutritious or require less energy to acquire. With knowledge of the existence of preferred foods at or near the forest boundary, only the relative abundance of the primates will determine the extent of raiding cause.

The zoning of Mabira forest reserve into management zones was done in principle, but illegal activities continue to alter the structure and composition of the forest in different parts. Alternatively, the forest has not had time to develop typical characteristics of the management zones. Therefore, the ecological differences do not significantly affect the population of crop raiders. Struhsaker (1997) showed that logging reduced the densities of social groups of all but one of the seven species of diurnal primates in Kibale. Plumptre and Reynolds (1994) made diverse observations of the effect of logging on different animal species.

\section{Conclusions and Recommendations}

This study set out to determine the extent of crop raiding in gardens located on the forest fringes as influenced by time of the season cropping mixtures and forest disturbance. The results show that the group size of raiders was significantly larger in the afternoon than in the morning and evening. Mean monthly raiding frequencies were generally higher in the July and August, coinciding with fruiting of most crops, followed by November and least in September and October. Cropping systems with highly palatable crops were more raided than those with less palatable crop species. Passion fruits were the most raided crops followed by maize, bananas and least was cassava. The maizecassava mixture experienced the lowest level of raiding followed by the banana-Coffee. Banana and maize were not different but experienced higher raiding that bananacoffee. Zones with intermediate disturbance experience higher levels of crop raiding compared to the low and high disturbance zones. The recreation buffer had signi- ficantly higher overall mean estimates of crop raiding compared to the production zone and nature reserve. Further studies are required to ascertain the economic loss to the farmers resulting from wildlife crop raiding, opportunity cost of control methods, crop yield gap attributable to crop raiding by wild animals, types, relative abundance and spatial distribution of primate foods within the different forest zones, and analysis of socio-economic factors (farm size, income, alternative economic activities and family size).

\section{ACKNOWLEDGEMENT}

We are indebted to Carnegie Corporation of New York for funding this study through the School of Graduate Studies, Makerere University. Farmers whose gardens were used to undertake the study are highly appreciated.

\section{REFERENCES}

Balasubramanian M, Baskaran N, Swaminathan S, Desai AA (1995). Crop raiding by Asian elephant (Elephas maximus) in the Nilgiri Reserve, South India. In: (Eds J. C. Daniel and H. S. Datye). A week with Elephants: Proceedings of the International Seminar on the Conservation of the Asian Elephant Oxford University Press, Bombay.

Baranga D (1995). The ecology and conservation status of the redtailed monkey, Cercopithecus ascanius schmidti, in the 'Kampala area'. PhD Thesis, Makerere University, Makerere, Uganda.

Baranga D (2004). Forest fragmentation and primates' survival status in non-reserved forests of the 'Kampala area', Uganda. African J. Ecol. 42:70-77

Baranga D (2007). Observations on resource use in Mabira Forest Reserve, Uganda. African J. Ecol. 45:1-6

Boulton AM, Horracks JA, Baulu J (1995). The Barbados vervet monkey (Cercopithecus aethiops sabaeus): Changes in population size and crop raiding 1980-1994. Intl. J. Primatol. 17: 831-844.

Chapman CA, Balcomb SR, Gillespie TR, Skorupa JJ, Struhsaker T (2000) Long-term effects of logging on African primate communities: a 28-year comparison from Kibale National Park, Uganda. Conserv. Biol. 14:207-217.

Chapman CA, Lambert JE (2000). Habitat alteration and the conservation of African primates: case study of Kibale National Park, Uganda. Am. J. Primatol. 50:169-185.

Chinea JD (2002). Tropical forest succession on abandoned farms in the Humacao Municipality of eastern Puerto Rico. Forest Ecol. Mgt. 167:195-207.

Chiyo PI, Cochrane EP, Naughton L, Basuta GI (2005). Temporal patterns of crop raiding by elephants: a response to changes in forage quality or crop availability? African J. Ecol. 43:48-55.

Cords M (1984). Mixed-species groups of Cercopithecus monkeys in the Kakamega Forest, Kenya. PhD Dissertation, University of Califonia Berkeley, USA.

Deodatus $F$ (2000). Wildlife raiding in rural areas with emphasis on Malawi, In: H. Prins, J. Grootenhuis, T. Dolan (Eds.), Wildlife Conservation by Sustainable Use, Kluwer Academic Publishers, Dordrecht.

Dunbar R (1988) Primate Social Systems. Croom-Helm, London, UK.

Else JG (1991). Non-human primates as pests. pp. 115-165. In: Box H. O. (editor): Primate Responses to environmental change. Chapman \& Hall, London. pp. 191-198.

Forest Department (1996). Mabira forest reserve biodiversity report: Report No. 13. FAO \& UNDP, Kampala

Fungo B (2011). A review of crop raiding around protected areas: Nature, Extent and research gaps. Environ. Res. J. 5(2):87-92. 
Fungo B., Twheyo M and Eilu G., 2010. Patterns of crop raiding around Mabiro Forest Reserve, Uganda. Res. J. Biol. Sci. 5(12):785-792

Groves CP (2007). The endemic Ugandan mangabey, Lophocebus ugandae, and other members of the albigena-Grup (Leuphocebus) Primate Conserv. 22:123-128.

Haule KS, Johnsen FH, Maganga SLS (2002). Striving for sustainable wildlife management: the case of Kilombero Game Controlled Area, Tanzania. J. Environ. Manag. 66:31- 42.

Hill CM (1997). Crop raiding by wild veterbrates: the farmers' perspective in an agricultural community in western Uganda. Int. J. Pest Manag. 43(1):77-84.

Hill CM (1999). Conflict of Interest Between People and Baboons: Crop Raiding in Uganda. Int. J. Primatol. 21(2):299-315.

Hill CM (2000). Conflict of interest between people and baboons: Crop raiding in Uganda. Int. J. Primatol. 21:299-315.

Howard C (1996). Nature Conservation in Uganda's Tropical Forests. IUCN, Kampala.

Howard PC (1991). Nature Conservation in Uganda's Tropical Forest Reserves IUCN, Gland, Switzerland and Cambridge, UK

Infield M, Namara A (2001). Community attitudes and behavior towards conservation: an assessment of a community conservation program around Lake Mburo National Park, Uganda. Oryx 35 (1):48-60.

Isawa Y, Higashi M, Yanamura N (1981). Prey distribution as a factor determining the choice of optimal foraging strategy. Am. Nat. 117:710-723.

Jackson R, Wangchuk R (2000). People-wildlife conflicts in the transHimalaya. Paper presented at Management Planning Workshop for the trans-Himalayan Protected Areas, Ladakh.

Krebs JR (1978). Optimal foraging: Decision rules for predators. In Behavioural Ecology: An Evolutionary Approach, ed. J. R. Krebs, N. B. Davies. Oxford: Blackwell 134.

Krebs JR (1980). Optimal foraging, predation risk, and territory defence. Ardea 68:83-90.

Likert R (1932). The Techniques for the Measurement of Attitudes. Arch. Psychol. 140:1-55.

MacArthur RH, Pianka ER (1966). On optimal use of a patchy environment. Am. Nat. 100:603-609

Maynard SJ (1978). Optimization theory in evolution. Ann. Rev. Ecol. Syst. 9:31-56.

Mole S (1994). Trade-offs and Constraints in Plant-Habivore Defence Theory: A Life-History Perspective Oikos 71:3-12.

Naughton-Treves L (1998). Predicting patterns of crop raiding by wildlife around Kibale National Park, Uganda. Conserv. Biol. 12: 156-168.

Naughton-Treves $L$ (2002). Wild animals in the garden: Conserving wildlife in Amazonian ecosystems. Ann. Assoc. Am. Geogr. 92(3):488-506.

Osborn L (1998). Ecology of crop raiding elephants. Pachyderm. 25:3945.
Plumptre AJ, Reynolds V (1994). The effect of selective logging on the primate populations in the Budongo Forest Reserve, Uganda. J. Appl. Ecol. 31:631-641.

Pyke GH (1984). Optimal Foraging Theory: A Critical Review. Annual Rev. Ecol. Systematics, 15:523-575.

Pyke GH, Pulliam HR, Charnov EL (1977). Optimal foraging: A selective review of theory and tests. Q. Rev. Biol. 52:137-54

Saj T, Sicotte P, Paterson DJ (1999). Influence of human food consumption on the time budget of vervets. Intl. J. Primatol. 20(6):977-994

Schoener TW (1971). Theory of feeding strategies. Ann. Rev. Ecol. Syst. 11:369-404

Siex KS, Struhsaker TT (1999). Colubus monkeys and coconuts: a study of perceived human-wildlife conflicts. J. Appl. Ecol. 36:10091020.

Sitati NW, Walpole MJ, Leader-Williams N (2005). Mitigating humanelephant conflict outside protected areas in Africa: crop raiding in Transmara District, Kenya. J. Appl. Ecol. 42:1175-1182.

Struhsaker TT (1997). Ecology of an African Rain Forest: Logging in Kibale and the Conflict between Conservation and Exploitation. University of Florida Press, Gainesville.

Sukumar R (1989). The Asian Elephant: Ecology and Management. Cambridge University Press, Cambridge p. 251.

Tweheyo M, Obua J (2001). Feeding habits of chimpazees (Pan troglodytes), red-tailed monkeys (Cercopithecus ascanius larvatus) and blue monkeys (Thercopithecus mitis stuhhlaine) on figs around Budongo Forest Reserve, Uganda. Afri. J. Ecol. 39:133-139.

Tweheyo M (2003). Abundance, distribution and phenology of chimpanzee food in the Budongo Forest Reserve, Uganda. PhD Thesis, Agricultural University of Norway, Oslo. 